\title{
Innovation management in a small enterprise in the state of Amazonas
}

Moisés Israel Belchior de Andrade Coelho (SECTI - AM/Brasil) - moises.acoelho@gmail.com

-Av. Mário Ypiranga Monteiro, 3280, Prédio I, Parque Dez, 69050-030, Manaus-AM

ABSTRACT This work aimed to identify and propose practical business focused on innovation management for small enterprises using the Temaguide model. The literature review focused on aspects related to innovation management and the management model used in the study. The work took place in a small enterprise in the food sector of the city of Manaus. The study took the form of an action research.The research approach is characterized as qualitative and indirect documentation (documentary research and literature), intensive direct observation (observation and interview), and extensive direct observation (forms) were the research techniques used. Results are presented in the application of the steps in the Temaguide enterprise model and innovations implemented. The relevance of this work consists of the presentation and adoption of a model for innovation management, in a small enterprise, which can be applied by the company itself or in collaboration with a university.

Keywords Innovation management. Entrepreneurship. Small Enterprise. Amazonas. 


\section{INTRODUCTION}

Currently, the knowledge and the technological advances in the development of new offers, products and services, and how they create and launch these offerings are an important competitive advantage. Innovation is something new that adds social value or wealth, going far beyond a new product, which may be related to new technologies, new processes, new marketing practices, small changes, etc. Innovation is not restricted only to manufactured goods, can be found in the service sector with enhancements involving promptness, quality and effectiveness of their care services (TIDD et al., 2008).

The competition based on prices given way to competition based on innovation, thus, there is a transformation of national systems of capitalism to a capitalism where the accumulation and innovation are in the hands of groups of enterprises organized transnational (FURTADO, 2008). According to Schumpeter (1961) innovation is the impetus that keeps running the machine of capitalism through a process called "creative destruction." The "creative destruction" allows opening to new opportunities and changes in existing players (BESSANT et al., 2005).

In 2012, micro and small enterprises (MSEs) in Brazil accounted for about 6.3 million establishments (99\% of total enterprises) accounted for 16.2 million formal jobs (51.7\%). In Amazonas, MSEs are more than 42,824 establishments represent $97.8 \%$ of all businesses in the state (SEBRAE; DIEESE, 2013). The mortality rate of MSEs in Brazil was very high, in 2007 the average mortality rate is around 24\% in Brazil. In the case of Amazonas this rate is around 40\% of micro and small enterprises Amazonians close before completing two years of existence, the second highest in Brazil (SEBRAE, 2013). In 2011 a total of 18,772 brazilian enterprises made exports of which 11,525 (61\%) were micro and small enterprises. Of the U.S. \$ 255.6 billion in exports of enterprises only U.S. $\$ 2.2(0.8 \%)$ billion of exports were made by MSEs (MOREIRA et al., 2012a). The Amazonas in 2011 exported \$ 914.1 million ( $0.4 \%$ of total exports from Brazil) through 231 firms, these 93 (40\%) were micro and small enterprises that exported U.S. \$ 15.7 million approximately $1.7 \%$ of the total state (MOREIRA et al., 2012b).

The above data allied to recent results of the 5th edition of the Survey of Technological Innovation - PINTEC corroborate the situation in which small businesses do not have or have few problems with innovative activities and the qualification of manpower (IBGE, 2013).

Therefore, has in the case of the Amazonas and Brazil a framework where the MSEs represent the vast majority of enterprises, however as we have features enterprises with high mortality (especially the Amazon), not exporters, problems with qualification of labor and little innovative. One way to survive, grow and develop sustainably in a globalized market where competitive advantages are strongly related to innovations is through a methodology that implements the innovation management in these organizations.

Hence, the relevance of this research consists in the presentation and adoption of a model for the innovation management, in a small enterprise, that can be applied by the company itself or by collaboration with a university in order to make it more competitive through innovations that meet their needs. The study is divided into four parts: (1) a review of literature dealing with innovation management studies grouped into macro and micro level, as well as the presentation of the model to be applied; (2) then presents the methodology used; (3) the application of the approach to innovation management in the enterprise studied; and (4) the final considerations and references. 


\section{LITERATURE REVIEW}

\subsection{Innovation management}

The process of innovation in enterprises can take many forms possible, as well as its implementation can be done in different ways in different sectors of the economy, however, there is the possibility of adopting models of innovation management in order to systematize the process of developing innovations in enterprises.

The innovation management helps the enterprise to innovate and position itself against the competition, helps to work with quality management standards and meet the requirements of the environment (COTEC, 1999). The effectiveness of innovation management is more related to the ability to manage an internal system of innovation with a number of dimensions than do one thing particularly well, such as investment in research and development (R\&D) and risk management, for example (BESSANT et al., 2005).

Studies of innovation management can be grouped into two categories in order to analyze different aspects of innovative processes as Nieto (2003):

1. Studies at the macro level: with the society, the economic system and the industry as units of analysis and much of the research conducted by industrial economics, sociology and history;

2. Studies at the micro level: The units of analysis a business, department, project or product.

Subsequently, Longanezi et al. (2008) describe two types of models of innovation management: (1) the descriptive models, and (2) the normative models. The descriptive models work with innovation in macro and meso levels (analysis unit of society, the economic system or industry) seeking a theory that explains the innovative process from the central questions such as "who, when, why and when". They are divided into static and dynamic, with the main focus of the static classification of different types of innovation and the dynamic evolution of the process in time. In this type of models can cite the work of Abernathy and Utterback (1978), Dosi (1982), Christensen (1997), Chesbrough (2003) and Berkhout et al. (2010).

The normative models analyze innovation at the micro level (the enterprise), originate from practical experiences and case studies and seek to analyze the modus operandi in the innovation process in enterprises. They can be easily made into procedures and practices to be adopted at the operational levels of enterprises and useful in implementing the strategies developed. As examples of this model is Kline and Rosenberg (1986), Rothwell (1994), Kelley and Littman (2001), Bessant et al. (2005), Sawhney et al. (2006), Hansen and Birkinshaw (2007), Tidd et al. (2008), Silverstein et al. (2009), Maital and Seshadri (2010) and Goffin and Mitchell (2010).

In Brazil, over the past few years many innovation management models have been developed, between them stand the tool presented by the National Confederation of Industries (CNI) to evaluate and deploy the management of innovation in firms. This tool was named MAPEL and aims to assess six dimensions, five related to the structuring processes and focused to evaluate the methods obtained (CNI, 2010). 
Analogously to CNI the Center for Advanced Studies of Recife (CESAR) developed the CESAR innovation process (PIC), this process is based on the principles of user-centered design, emphasizing the understanding of people to develop user experiences that improve their quality of life (CESAR, 2009).

At work, Longanezi et al. (2008) proposes a model that integrates the key activities and best practices recommended in the literature focused on a management system. The model consists for six integrated stages: (1) ambient intelligence; (2) definition of technological and market strategies; (3) identification of opportunities; (4) selection and prioritization; (5) development and implementation; and (6) evaluation system and process metrics.

\subsection{COTEC MODEL}

The model of innovation management Cotec - Temaguide is the result of a survey conducted by a group of European organizations having COTEC Foundation as coordinator of the project, the enterprise also participated SOCINTEC the CENTRIM (University of Brighton), the IRIM (University Kiel) and R\&D unit of the Manchester Business School. This project was approved by the innovation program of the European commission (COTEC, 1999). The Temaguide is composed of five elements (scan, focus, resource, implement and learn) and supported by tools and techniques that suggest the development of a project or activity there is a cycle of interactive learning rather than a simple process with consecutive phases (Figure 1).

Figura 1 - Cotec Innovation Management Model - Temaguide.

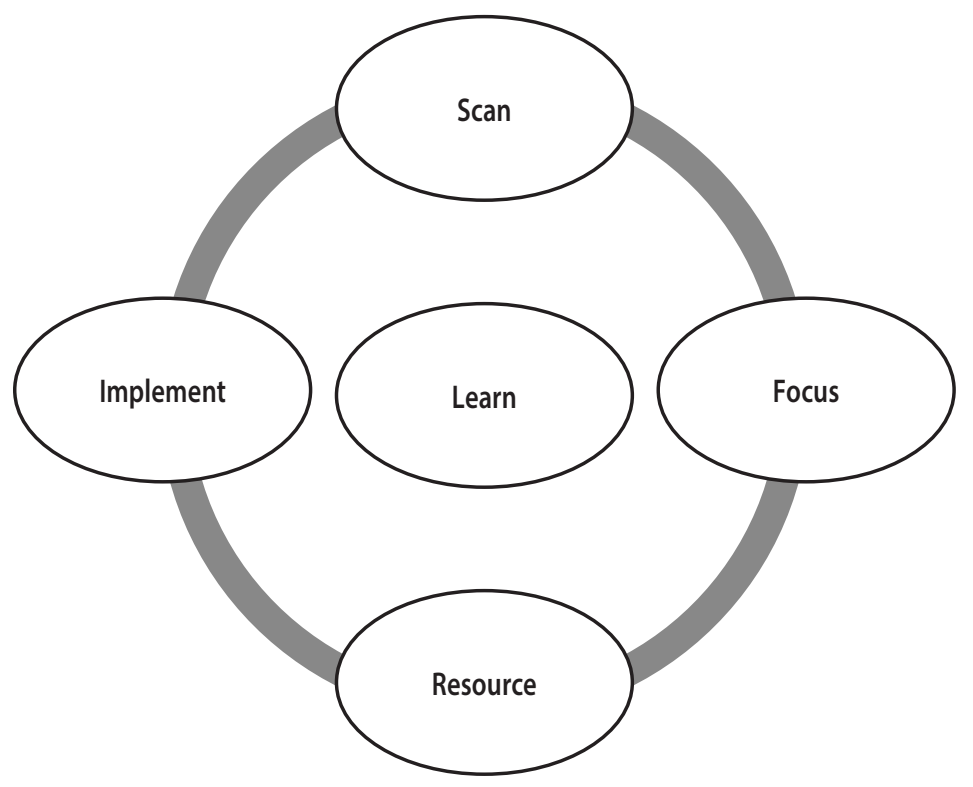

Source: Coteec, 1999. 
Scan is the exploration continues the internal and external environment for the identification and processing of signals, signs or opportunities of such importance that a response is required by the organization. The Focus is the definition of a strategic response based on information from the prospecting stage and assumes that resources are limited across the organization. Focus is to select the action lines that offer the greatest opportunity for competitive advantage.

In phase resource the objective is to define a set of activities aimed at organizing skills for the correct functioning of the innovation process, both in relation to knowledge, as technology or equipment.

The fourth phase, implement, is the core of the innovation process, considering that this stage is that innovation becomes reality. The efficiency is a hallmark of this stage since the enterprise was qualified, a good definition of the innovation project facilitates the advancement of it in its various stages, especially at this stage of implementation. Finally, the last phase, learn can be seen as a moment of feedback that lets you know how the system works in order to improve it, evaluate the knowledge to modify the defects that may have occurred (COTEC, 2004).

This model serves both to businesses organized as classical functions (HR, marketing, production, sales, etc.), as the firms working on cases, you can apply it to a project or organization as a whole. Thus, the Temaguide is not only a process model of technological innovation, but also a model of innovation at the organizational level that serves both for enterprises and for industrial services enterprises with a view that technology is important for any type organization and any industry (COTEC, 1999).

\section{METHODOLOGY}

\subsection{Study design}

This study, in terms of approach to your problem, characterized as a qualitative research (SILVA; MENEZES, 2005), where he worked an enterprise in the food sector in the city of Manaus. In relation to their goals, this work is characterized as an action research (GIL, 2002; TRIPP, 2005; THIOLLENT, 2007; MCNIFF, 2002), it was concerned with the resolution of organizational problems through the application of management tools innovation in a small enterprise in the state of Amazonas in practice.

In this study, the model used for the innovation management was the model developed by COTEC $(1999,2004)$, also known as Temaguide. The management of technology and innovation model derive five steps (scan, focus, resource, implement and learn) that will be used throughout the action research. The choice of this model arises from the considerable amount of articles and books available as a way to explain theoretically the study and sustain action research. 


\subsection{Characterization of the enterprise}

The enterprise Alpha is a small enterprise with 21 employees located in Manaus, in the business of baking for over 15 years and has as main products manufactured breads, cakes, pies, donuts, chips, snacks, sandwiches, and breakfast. The same provides for local small and medium industries. The distribution for enterprises happens in the early morning and late afternoon. Access to the enterprise occurred through previous contact with the owner via professional indication.

The owner of the enterprise Alpha has 52-year-old native of Amazonas, as training has finished high school and his presence in the enterprise so happens shared, financial issues and people management are managed by his wife and the productive aspects and distribution are the responsibility of the owner.

\subsection{Methods of data collection}

The delimitation of the universe was composed of a small enterprise located in the city of Manaus/AM in the food sector, more specifically, bakery. Access via the enterprise was professional contact, the initial stages (scan, focus and resource) generally demanded 45 days and step to implement the actions lasted five months. The sample studied was a non-probabilistic intentional (MARCONI, 1990). The research techniques used to operationalize the study were: (1) the indirect documentation (desk research and literature), (2) the intensive direct observation (observation and interview), and (3) the extensive direct observation (forms).

This research used open structured interviews, individual (owners) and collective (employees), from a screenplay where identified key information and additional forms applied in the enterprise studied (VERGARA, 2009). In the case of meeting, they followed the approach proposed by Thiollent (2007) as a source of data collection of action research. The structured observation (VERGARA, 2009) was another technique used to identify characteristics of employees and owners with the aim of better understanding of reality.

The observation came from global methodology Guérin et al. (2001) in which from the collective and individual interviews (demand) the observer conducted a brief analysis of tasks with a particular focus in the area of baking. There were considered observable, gestures, postures, actions and communications between the bakers and helpers, and communications with other areas (confectionery, store and administration).

The forms (adapted) used: (1) audit capacity (FNQ, 2009a; 2009b), (2) innovation audit (DE JONG; MARSILI, 2006; FREEL, 2003; 2005; VERMEULEN; DE JONG, 2006); (3) benchmarking (BÜYÜKÖZKAN; MAIRE, 1998), (4) selection of opportunities (CARVALHO, 2009), (5) definition of resources (CARVALHO, 2009), and (6) planning for innovation (HARVARD BUSINESS ESSENTIALS, 2011) for application of techniques/tools of innovation management at the enterprise.

The tools and techniques used in this research and applied in Alpha Enterprise are presented in box 1. Aiming to maintain the confidentiality of the enterprise will be called Alpha enterprise, this secrecy was requested by the owners. Altogether individual interviews were conducted with two individuals, one owner and the other a financial officer of the enterprise. The duration of the interview was between 60 minutes and 90 minutes. 
The next day the interviews occurred application of capability audit, innovation audit and SWOT analysis that required between 45 minutes and 60 minutes, because often the information was supplemented by information from the owners. Both interviewees opined in an open and spontaneous way. Regarding collective interviews with workers, they occurred with 16 employees (out of a total of 21 employees), the systematics of these interviews took place in the enterprise sectorally (bakery, confectionery and store) and the average duration of these interviews was 30 minutes in each sector due to occur during daily activities.

Box 1 - Methods and tools adopted in the case.

\begin{tabular}{|c|l|}
\hline Steps & \multicolumn{1}{|c|}{ Methods and tools } \\
\hline & $\begin{array}{l}\text { Individual interview } \\
\text { Collective interview } \\
\text { Sirect observation } \\
\text { Innovation Audit } \\
\text { Audit capacity } \\
\text { Benchmarking } \\
\text { Trend Analysis }\end{array}$ \\
\hline Focus & $\begin{array}{l}\text { Map of current situation } \\
\text { Meeting } \\
\text { Selection of opportunities }\end{array}$ \\
\hline Resource & Resource definition \\
\hline Implement & Innovation planning \\
\hline Learn & Learn check list \\
\hline
\end{tabular}

Source: Author.

\section{DATA ANALYSIS AND RESULTS}

This topic will be presented the steps of Temaguide model in the enterprise studied. Then, occurs analysis of the results, the transformations and innovations implemented in the case.

\subsection{Scan}

The study in Alpha enterprise began with visits where there were interviews with the owner and financial manager in order to better understand the enterprise identifying the main difficulties faced by same. Later the interview with the owner SWOT analysis was performed to identify the strengths, weaknesses, opportunities and threats.

Concurrent SWOT analysis were applied forms of audit capacity (Figure 2) and innovation audit (figure 3). In a second phase, interviews were conducted with employees of the enterprise's three sectors (confectionery, bakery and store) in order to identify potential difficulties and demands for improvements in the workplace. These interviews took place in a collective way and without the presence of the owners aiming to take advantage of better answers. 
Direct observation (non-participant) totaled seven hits, two observations made in confectionery, three observations made in the bakery and two observations made in the store. The duration of the observations was two hours on average and sought to understand the gestures, postures, actions and communications between employees of sectors and each other.

To identify possible trends in the sector was used publication SEBRAE and ABIP (2009), access to the site PROPAN (Support Program Bakery) and a visit to SEBRAE (Brazilian Service Support to Micro and Small Enterprise) was performed.

Again the information gathered in the interviews with the owners and employees were added to the results of the two forms (audit and audit capacity for innovation), SWOT analysis, benchmarking and direct observations allowing to identify the main demands of the organization. For the step of collecting information were required visits the enterprise Alpha 13 a 30 day period including the period of data analysis.

\subsection{Focus}

In this step was developed and presented to the owner and employees of the enterprise in the form of a meeting the Map of the current situation of the enterprise were inserted the results of the tools and techniques used in the stage of exploration, as well as the probable solutions and/or actions to be developed.

At the meeting it was discussed as to what actions could be worked on immediately and which would be postponed for a second time. From a total of 19 shares, ten were chosen for use in the worksheet to select the opportunities (financial control, standardizing production; Program 5s; production plan; HVAC (heating, ventilation and air conditioning); strategic plan, new product development, people management, production layout, developing partnerships). The criteria used by the owner were: (1) the ratio profit/investment, (2) reducing costs, (3) improving the work environment, and (4) ease of implementation, similar to Alpha Enterprise. The criteria received a score (1 - low, 3 - medium and 5 - high) according to the impact of innovation in relation to them.

The points were prioritized by the spreadsheet:

1. 5 S program;

2. Productive standardization;

3. Production plan;

4. Changing the layout of the store and productive

5. People management;

6. New product development.

From a total of 19 actions presented on the map of the current situation, six actions were prioritized in order to facilitate the implementation and monitoring of the same. 


\subsection{Resource}

At this time we used the definition of spreadsheet allocation of resources for each of the six main actions related to key aspects of the company (human resources, infrastructure, technology and financial resources). The purpose was to describe the resources needed to achieve the goal of every action and which forms of access to these resources.

Thus one has a complete picture to the next step (implement) of which the company has resources, or just need to develop and what resources need to be acquired. In this case, all five actions, in respect to human resources, it was necessary to search the company external sources. In terms of infrastructure were not necessary modifications in the structure of the property, only the layout of the production and store. Concerning the source of funds the company financed on their own all the shares.

\subsection{Implement}

Finally, at this stage we used the planning for innovation in order to identify what the main idea and what type of innovation will be adopted, which shares short and long term and what measures will be used as parameters for actions.

The six lawsuits originated three schedules for innovation containing the information mentioned above, with this; the enterprise has defined the resources that will be needed to meet the diverse actions. Creating a schedule of training was required for the training of owners and employees in view of the changes. Then we present the details of the main actions that occurred in the implement stage.

5S Program: the partnership with SENAC (National Commercial Training Service) enabled the implementation of the $5 \mathrm{~S}$ program through employee training and periodic monitoring by the Safe Food Program (SBP). The Alpha enterprise organized and identified the locations of productive areas and store with labels identifying raw materials (food), the wooden balconies have been replaced with aluminum counters, the floor has to be cleaned daily and was set for a weekday cleaning machines.

Productive standardization: the preparation and application of technical files of the product portfolio of the enterprise (bakery, confectionery and store) were being deployed consist of: ingredients, quantity gross/net, unit cost/total mode of preparation, assembly and decoration. The information was collected directly from employees.

To reduce losses of raw materials we prepared a form for inventory control (entry and exit of materials) for completion by staff, preparing spreadsheet for expense control materials in conjunction with the production plan and the datasheets. The Alpha enterprise production prepared kits that are assembled exclusively by an official in order to further reduce waste. The kits are sent to manufacturing production as the production sequence presented in daily production plan. Only the yeast does not enter into kits production because its amount varies according to temperature. 
Production plan: the production plan has been prepared and discussed with the owner and responsible for production, it was due to the laborious process of delivery of bread in client enterprises influence the production process. There are two productions of bread, one in the morning and one in the afternoon. The production is defined by the number of products distributed to each enterprise plus store sales forecast for the period.

Changing the layout: the store layout had to be changed by the limited mobility of people internally ally this situation deployment of services with foods and pizza lunch (from 19:00) demanded the enterprise adequacy of this area and the hiring of six new staff (two staff for lunch and pizza for the other four, including a pizzaiolo) with the SINE (National Employment System). The layout was altered baking productive through the exchange of the wood stove, which occupied a lot of space for two gas furnaces. Again the choice of the gas oven instead of electric furnace resulted from the instability of power supply in the city of Manaus. Production machines have been aligned according to the production flow.

People management: the people management has undergone transformations through the adoption of uniforms for employees, distribution of basic food for employees who have no absences or delays, overtime payments rather than the bank of hours, not to mention the improvements in the work environment (treatment between owners and employees) that causes a high level of dissatisfaction among employees. The owners and staff training has influenced this process of organizational change.

New product development: the Alpha enterprise aiming to expand its product line developed a line of breads based on cassava starch and Brazil-nut (Bertholletia excelsa). The cassava starch was used in the proportion of $10 \%$ relative to the amount of flour and this allowed a reduction of production costs allowing the inclusion of Brazil nuts without raising the price of the product. The Brazil-nut was also used in confectionery for the formulation of regional pies and cakes. Added to the Brazil-nut, the enterprise started using the cupuaçu, cupulate (cupuaçu benefited in the form of chocolate) and puxuri (Licaria puchury-major) as the basis for their pies and cakes. The puxuri, also known as angel smell, is used as a cosmetic or food flavoring and was initially used as a medicinal properties in the treatment of insomnia and cramps.

\subsection{Learn}

The learn stage served as a reflection and improvement of knowledge regarding the current state of the enterprise upon presentation and discussion of results between different organizational actors (owners and employees).

In the implementation phase of prospecting tools and techniques enabled the enterprise Alpha a far broader not only internally more than externally market where it operates. As difficulties, the development of trust in employees only occurred with the development of intervention. The extraction of information from employees, at press conferences was cornered at the beginning due to distrust of a natural process of organizational transformation. 
The implement stage results demonstrated the need for the intervention to be performed step by step to avoid mistrust of employees in changing their routines. As difficulties, high distrust of officials with the change in routine caused a drop in productivity and questions at the beginning of the action.

Thus the model allowed the occurrence of innovations outside of what had been planned, the implementation stage was the longest and most delicate by direct relationships with employees, the organizational change process and the exchange and acquisition of new knowledge.

\subsection{Analysis of results and innovation}

Regarding the results obtained in Alpha Enterprise of the six proposed actions focus on step: productive standardization, production plan, changing the layout, people management, new product development and 5S Program.

- Standardizing production occurred through the development of production datasheets;

- There were improvements in people management in Alpha enterprise, such as uniforms, basket, overtime pay (instead of bank hours), without extra pay to staff shortages or delays;

- Change the layout of the store were productive and the expansion of confectionery, wood stove exchange and by offering new services to food service;

- Plan production contributed to a better control of daily production in conjunction with the tools to inventory control and production kits;

- The 5S program was implemented with the help of a partnership with SENAC to sensitize employees to the adequacy of the enterprise PAS (Safe Food Program) and internal improvements of organization and cleanliness;

- The new products developed using Amazonian inputs (cassava starch, Brazil-nut, cupuaçu, cupulate and puxuri) expanded the product portfolio, and develop a completely regional product line focusing on clientele of tourists visiting the city.

In the study with the Alpha enterprise radar analysis of audit capacity (Figure 2) showed considerable improvements in aspects related to production management (before 1.26 and after 1.91), especially the primary and secondary processes (before 1.00 and after 2.82) resulting from productive innovations and enterprise management (1.18 before and after 2.50 ), especially the strategic (before 1.00 and before 3.27) resulting from the use of planning for innovation. The people management dimension showed significant increases (before 1.15 and after 2.30) due to improvements in working conditions and partnerships for capacity building and training. The dimensions of marketing management and information management showed no significant increases due to the focus of the intervention may not be related directly to these dimensions. 
Figure 2 - Audit capacity (before and after) - Alpha Enterprise.

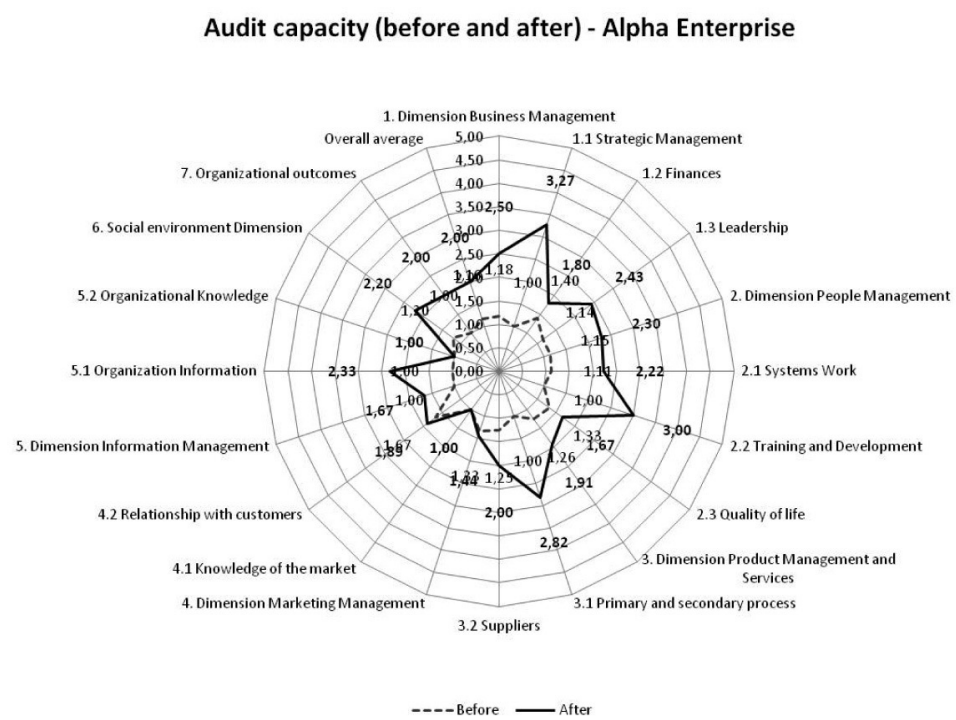

Source: Author.

The radar chart audit of innovation (Figure 3) showed considerable increases mainly in the dimensions innovation input (before 1.00 and after 2.50), especially in training/development programs and adoption of a budget for innovations, in planning dimension of innovation (before 1.00 and after 4.00), the use of planning for innovation, and the dimension external guidance for the acquisition of knowledge and external collaboration (1.33 before and 2.33 after). In the output dimension of innovation, new products developed by the company, process improvements and organization provided an increase from 1.13 to 2.75. As negative points highlight the scale sources of innovation with no action developed with suppliers, competitors and through scientific development. Also there were innovations in marketing and cooperation among enterprises because of the same are not related to organizational intervention. 
Figure 3 - Innovation audit (before and after) - Alpha Enterprise.

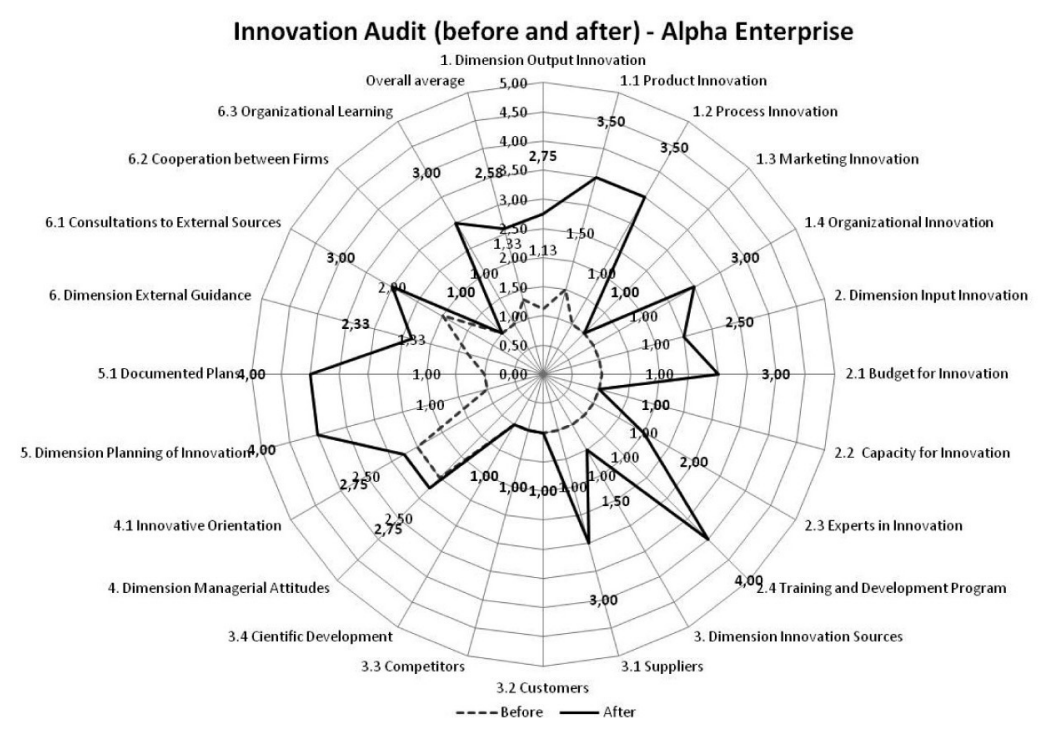

Source: Author.

\section{FINAL CONSIDERATIONS}

This study attempts to demystify the process of innovation management for MSEs from the adoption of a model to be applied by the enterprise itself or by collaboration with a university. The discussion by the spread of innovation management is necessary to reduce the negative data MSEs, not only in the state of Amazonas, but also in Brazil enabling these enterprises to the competitiveness necessary for their survival and development.

The innovation management model used (Temaguide) in enterprise allowed to identify, implement and evaluate the adoption of business practices appropriate management of innovative processes, thus the aim of the research was achieved, as well as the question-problem answered. The entrepreneurial attitude toward innovation is crucial to organizational success as shown in Dyer et al. (2009) and corroborated by this study.

Can be highlighted as main results: (1) a survey of the major internal and external aspects inherent competitiveness of enterprise, (2) adoption of a methodology and tools for innovation management, (3) developing a plan of action and planning for innovation, (4) presentation and discussion with employees and owners of major innovations necessary actions aiming and internal improvements, (5) implementation of innovations (new product development) and improvements in enterprise, (6) acquisition of internal and external knowledge and (7) use of spyder chart enabled showing the before and after intervention. 
As a proposal for future studies may be suggested to apply the methodology of Temaguide in other traditional sectors or technology-intensive sectors MSEs. The use of methodology in medium and large business would also be a second suggestion for studies.

In summary, the results demonstrate the utility of Temaguide aimed at increasing competitiveness and working conditions in MSEs, but there is the need of the effectiveness of a triple helix model (university-industry-government) that operates and provides the MSEs interactions necessary for the emergence and development of innovations. The relevance of this research consists in the presentation and adoption of a model for the innovation management in small enterprises.

\section{REFERENCES}

ABERNATHY, W. J.; UTTERBACK, J. M. Patterns of industrial innovation, Technology Review, v. 80, n. 7, pp. 40-7, 1978.

BESSANT, J.; LAMMING, R.; NOKE, H.; PHILLIPS, W. Managing innovation beyond the steady state, Technovation, v. 25, n. 12, pp. 1366-1376, 2005.

BERKHOUT, G.; HARTMANN, D.; TROTT, P. Connecting technological capabilities with market needs using a cyclic innovation model, R\&D Management, v. 40, n. 5, pp. 474-90, 2010.

BÜYÜKÖZKAN, G.; MAIRE J. L. Benchmarking process formalization and a case study. Benchmarking for quality management and technology, v. 5, n. 2, pp. 101-25, 1998.

CARVALHO, H. G. Gestão da Inovação: inovar para competir: Manual do participante. Brasília: SEBRAE, 2009.

CESAR - CENTRO DE ESTUDOS AVANÇADOS DO RECIFE. Processo de Inovação C.E.S.A.R. Recife: CESAR, 2009. Available: <http://cesar.org.br/site/cesar/processo-de-inovacao >. Acessed: january 20, 2013.

CHRISTENSEN, C. The Innovator's dilemma: when new Technologies cause great firms to fail. Boston, Massachussetts: Harvard Business School Press, 1997.

CHesbrough, H. W. The era of open innovation. MIT Sloan Management Review, v. 44, n. 3, pp. 35-41, 2003.

CNI - CONFEDERAÇÃO NACIONAL DA INDÚSTRIA. Cartilha Gestão da inovação. Brasília: CNI, 2010.

COTEC - FUNDACIÓN COTEC PARA LA INNOVACIÓN TECNOLÓGICA. Pautas metodológicas de la gestión de la tecnologia y de a innovación para empresas - Temaguide. Tomo I. Introducción, Presentación, CD y Módulo I: “Perspectiva Empresarial”. Madrid: Cotec, 1999.

COTEC - FUNDACIÓN COTEC PARA LA INNOVACIÓN TECNOLÓGICA. Análisis del processo da innovación en las empresas de servicios. Madrid: Cotec, 2004.

DE JONG, J. P. J.; MARSILI, O. The fruit flies of innovations: a taxonomy of innovative small firms, Research Policy, v. 35, pp. 213-229, 2006. 
DE JONG, J. P. J.; VERMEULEN, P. A. M. Determinants of product innovation in small firms. International small business journal, v. 24, n. 6, pp. 587-609, 2006.

DOSI, G. Technological paradigms and technological trajectories: a suggested interpretation of the determinants and directions of technical change. Research Policy, v. 11, pp. 147-162, 1982.

DYER, J. H.; GREGERSEN, H. B.; CHRISTENSEN, C. M. The inovator's DNA. Harvard Business Review, v. 87, n. 12, pp. 1-7, 2009.

FREEL, M. S. Sectoral patterns os small firm innovation, networking and proximity. Research Policy, v. 32, pp. 751-770, 2003.

FREEL, M. S. Patterns of innovation and skills in small firms. Technovation, v. 25, pp. 123-134, 2005.

FNQ - FUNDAÇÃO NACIONAL DA QUALIDADE. Critérios compromisso com a excelência e Rumo à excelência. São Paulo: Fundação Nacional da Qualidade, 2009a.

FNQ - FUNDAÇÃO NACIONAL DA QUALIDADE. Critérios de excelência/Fundação Nacional da Qualidade. São Paulo: Fundação Nacional da Qualidade, 2009b.

FURTADO, C. Criatividade e dependência na civilização industrial. São Paulo: Companhia das letras, 2008.

GIL, A. C. Como elaborar projetos de pesquisa. 4. ed. São Paulo: Atlas, 2002.

GOFFIN, K.; MITCHELL, R. Innovation management: strategy and implementation using the pentathlon framework. 2. ed. London: Palgrave, 2010.

GUÉRIN, F. KERQUELEN, A.; LAVILLE, A.; DANIELLOU, F.; DURAFFOURG, J. Compreender o trabalho para transformá-lo: a prática da ergonomia. São Paulo: Blücher: Fundação Vanzolini, 2001.

HANSEN, M. T.; BIRKINSHAW, J. The innovation value chain. Harvard Business Review, v. 85, n. 6, p. 121-130, 2007.

HARVARD BUSINESS ESSENTIALS. Harvard Business Online/support tools, 2011. Available: <http://www.elearning.hbsp.org/businesstools/>. Accessed: february 10, 2011.

IBGE - INSTITUTO BRASILEIRO DE GEOGRAFIA E ESTATÍSTICA. Pesquisa de inovação tecnológica - PINTEC - 2011. Rio de Janeiro: IBGE, 2013. Available: <http://www.ibge.gov.br/home/ estatistica/economia/>. Accessed: january 20, 2014.

KELLEY, T.; LITTMAN, J. A arte da inovação. 2. ed. São Paulo: Futura, 2001.

KLINE, S.; ROSEMBERG, N. An Overview of Innovation. In: LANDAU, R.; ROSEMBERG, N. The Positive Sum Strategy. Washington D.C.: National Academy Press, 1986.

LONGANEZI, T.; COUTINHO, P. L. A.; BOMTEMPO, J. V. M. Um modelo referencial para a prática da inovação,. Journal of technology management and innovation, v. 3, n. 1, pp. 74-83, 2008. 
MAITAL, S.; SESHADRI, D. V. R. Innovation management: strategies, concepts and tools for growth and profit. 5. ed. New Delhi: Sage, 2010.

MARCONI, M. A. Técnicas de pesquisa: planejamento, e execução de pesquisas. Amostragens e técnicas de pesquisa. Elaboração, análise e interpretação de dados. 2.ed. São Paulo: Atlas, 1990.

MCNIFF, J. Action research for professional development: concise advice for new researchers, 2002. Available: <http://www.jeanmcniff.com/ar-booklet.asp>. Accessed: june 16, 2011.

MOREIRA, R.; GAMA, H.; SCHERMA, M.; BEDE, M.; FONSECA, P.; MOURA, A. As micro e pequenas empresas na exportação brasileira: 1998-2011. Brasília: SEBRAE, 2012a.

As micro e pequenas empresas na exportação brasileira. Estados: 1998-2011. Brasília: SEBRAE, 2012b.

NIETO, M. From R\&D management to knowledge management. An overview of studies of innovation management. Technological Forecasting and Social Change, v. 70, pp. 135-161, 2003.

ROTHWELL, R. Towards the fifth-generation innovation process. International Marketing Review, v. 11, n. 1, pp. 7-31, 1994.

SAWHNEY, M.; WOLCOTT, R. C.; ARRONIZ, I. The 12 different ways for companies to innovate. MIT Sloan Management Review, v. 47, n. 3, pp. 75-81, 2006.

SCHUMPETER, J. A. Capitalismo, socialismo e democracia. Rio de Janeiro: Fundo de cultura, 1961. SEBRAE - SERVIÇO BRASILEIRO DE APOIO ÀS MICRO E PEQUENAS EMPRESAS. Sobrevivência das empresas no Brasil. Coleção Estudos e Pesquisas. Brasília: SEBRAE, 2013.

. ASSOCIAÇÃO BRASILEIRA DA INDÚSTRIA DE PANIFICAÇÃO E CONFEITARIA

- ABIP. Estudo de tendências: perspectivas para a panificação e confeitaria. Brasília: SEBRAE, 2009.

DEPARTAMENTO INTERSINDICAL DE ESTATÍSTICAS E ESTUDOS SOCIECONÔMICOS - DIEESE. Anuário do trabalho na micro e pequena empresa 2013. 6. ed. Brasília, São Paulo: SEBRAE, 2013.

SILVA, E. L.; MENEZES, E. M. Metodologia da pesquisa e elaboração de dissertação. 4. ed. rev. atual. Florianópolis: UFSC, 2005.

SILVERSTEIN, D.; SAMUEL, P.; DECARLO, N. The innovator's toolkit: 50+ techniques for predictable and sustainable organic growth. New Jersey/USA: Wiley, 2009.

TIDD, J.; BESSANT, J.; PAVITT, K. Gestão da inovação. 3. ed. Porto Alegre: Bookman, 2008.

THIOLLENT, M. Metodologia da pesquisa-ação. 15. ed. São Paulo: Cortez, 2007.

TRIPP, D. Pesquisa-ação: uma introdução metodológica. Educação e pesquisa, v. 31, n. 3, pp. 443466, 2005.

VERGARA, S. C. Métodos de coleta de dados no campo. São Paulo: Atlas, 2009. 